\title{
Labour productivity statistics: a reality check for the Norwegian Construction industry
}

\author{
Saad Bin Saleem Ahmad ${ }^{\mathrm{a} *}$, Muhammad Usman Mazhar ${ }^{\mathrm{b}}$, Amund Bruland ${ }^{\mathrm{a}}$, Bjorn \\ Andersen $^{\mathrm{a}}$, Jan Alexander Langlo ${ }^{\mathrm{c}}$ and Olav Torp ${ }^{\mathrm{a}}$ \\ ${ }^{a}$ Department of Civil and Environmental Engineering, Norwegian University of \\ Sciences and Technology, Trondheim, Norway \\ ${ }^{b}$ Department of Management, Nottingham Business School, Nottingham Trent \\ University, Nottingham, NG1 4BU, United Kingdom \\ ${ }^{c}$ SINTEF- Technology and Society, Trondheim, Norway
}

\begin{abstract}
Construction is one of the largest sectors that drive the global economy, yet it has failed to receive the necessary attention from the policymakers and investors. The existing construction statistics report the declining state of labour productivity. However, existing statistics often fail to reflect the true scope and economic impact of construction. They mainly account for on-site construction activities, but overlook the manufacturing of construction products and services in construction labour productivity statistics. The aim of this research is to investigate macro-economic labour productivity and identify the methodological problems inhibiting the effective measurement of construction labour productivity. The paper opted for academic literature review and a case study strategy for data collection. The findings reveal that many productive construction activities related to construction products and services are excluded from the construction labour productivity statistics. The results suggest that Norwegian construction labour productivity is not declining and is actually a productive industry in terms of value added per working hour. Although special reference has been made to the Norwegian construction industry, the same approach holds validity at the international arena of construction statistics. The study offers insights and lessons to construction industries of other countries facing similar productivity related issues.
\end{abstract}

Keywords: Construction statistics; labour productivity; productivity measurement Subject classification codes: Construction management; Construction economics 


\section{Introduction and background}

Productivity is amongst the most important and influential variables governing economic production activities (Singh, Motwani and Kumar, 2000; Tangen, 2005). Despite the economic perspective of productivity, the world's population has for the first time exceeded seven billion people and construction industry is responsible for meeting the physical demands of the vast majority. Therefore, the construction sector's productivity, both socially and economically, will be important to achieve resource efficiency in order to meet the sustainable development goals. As productivity is an important factor in social prosperity and sustainability, productivity improvement has remained one of the top policy priorities in the European Union's (EU) Lisbon agenda.

Construction industry has persistently pursued the improvements of the labour productivity; one of the primary reasons in this pursuit has been the costs associated with labour. The labour costs account for $30-40 \%$ of the total construction costs (McNally and Havers, 1967; McTague and Jergeas, 2002). On the other hand, the Organisation for Economic Co-operation and Development (OECD) encourages productivity measurements with a purpose to trace technological change, identify changes in the efficiency, recognize real cost savings in production, benchmark production processes for best practices and assess the living standards. Construction industry is in practice of using three common productivity indices; multi-factor productivity, labour productivity and capital productivity (RCBCI, 2002). Relating to the productivity measurements, this paper focuses on labour productivity, which is referred to as the real value added per hour work by the OECD (2015).

Statistical databases, such as the Eurostat, European Union (EU) KLEMS, United Nations Statistical Commission (UNSC) and OECD provide and publish overall and cross-country productivity analysis. In light of the EU KLEMS statistical database, 
several EU KLEMS member countries are facing the challenge of declining construction labour productivity. A plethora of academics, for examples Egan (1998) and Latham (1994), have indicated the decline of construction productivity. Therefore, improving construction labour productivity has been at the heart of national governments and construction industry's strategic agenda leading to various policy initiatives (Vogl and Abdel-Wahab, 2015). An understanding of construction labour productivity measurement is therefore essential for helping the policymakers and practitioners to take effective actions. This research focuses on investigating the weaknesses in macro-economic construction labour productivity measurements.

Academic evidence suggests that construction productivity measurements at macro and micro levels yield different results. Diverging trend indicates weakness between the aggregate and activity level productivity measurements (Abdel-Wahab and Vogl, 2011; Goodrum, Haas, and Glover, 2002; Pearce, 2003). Evidence from the literature and the Eurostat labour productivity statistics generates ambiguity around the state of macro-economic labour productivity measurements.

Therefore, the aim of this paper is to conduct an in-depth exploration of macroeconomic labour productivity measurements and indicate the methodological problems that may inhibit the construction labour productivity measurements. Despite the strategic importance of the construction industry, attempts to capture its true scope have been rather incomplete (Squicciarini and Asikainen, 2011). The quality of construction industry statistics have caused dissatisfaction amongst the academic and professional community (Ruddock, 2008). One of the prime causes of falling construction industry statistics reliability is the incompleteness and narrowness of the statistical definition of construction sector (Briscoe, 2006; Pearce, 2003; Squicciarini and Asikainen, 2011). According to Briscoe (2006), the statistical definition of construction sector fails to 
capture the construction services and construction products in productivity analysis. Moreover, it fails to capture the change in quality of construction output over time. It also neglects the improvements in the life cycle value of construction projects, which has significant effect on construction productivity.

A case study is designed to answer the question: is construction labour productivity really declining? The data from the Norwegian construction industry is used to explore the deviation in labour productivity results between the narrow statistical definition of construction sector and the wider definition of construction sector as proposed by Briscoe (2006) and Pearce (2003). In order to achieve this, the statistical classification of economic activities practiced in European community (NACE Rev. 2) was analysed to identify the economic activities of construction products and services outside the official statistical definition of construction. The labour productivity growth of construction products and services is integrated with the labour productivity statistics of construction sector to reach the conclusions. This approach does not require any changes in statistical principles or data generation and aggregation. Even though the Norwegian construction industry's data is used for this study, a similar approach holds validity with the EU KLEMS and Eurostat statistical databases. The study is not aimed at true valuation of the Norwegian construction industry rather it only collects the necessary evidence to determine if the Norwegian construction labour productivity is in real decline.

\section{Construction Labour Productivity Statistics}

Construction Labour Productivity statistics are the labour productivity (LP) measurements commissioned by the national governments and international statistical organisations such as Eurostat and OECD. Statisticians relate productivity to the 
measure of efficiency of the production process and categorise that process as an 'activity' in which different production factors such as raw materials, capital and labour combine to create specific goods or services. According to OECD (2001), LP is only a partial reflection of the personal capacities of workers, but it reflects the efficiency with which labour is combined with other factors of production. However, productivity comparisons have a long history of questionable validity and reliability, both from practitioners and the academic community (Rojas and Aramvareekul, 2003; Teicholz, Goodrum and Haas, 2001). In the context of construction LP, statistical discrepancies may depend upon the method of measurement, classification system, input data and output data.

\subsection{Method of measurement}

The EU KLEMS database provides a consistent structure to collect input and output data across different industries and between the variables for comparing the productivity growth rooted within the neo-classical production theory (O'Mahony and Timmer, 2009). According to neo-classical economic theory presented by Tinbergen (1942), savings generate growth in capital input and population growth generates growth in labour input. However, the method of measurement depends on the purpose of the productivity analysis. Based on input and output, there are many possible ways in which the construction LP can be measured depending upon the level of measurement (Thomas et al., 1986). Edkins and Winch (1999) categorised three basic approaches to measuring productivity as macroeconomic, case and pricing studies, the choice of which is dependent upon many factors such as the level of aggregation, data source (input/output) and boundary of the production process (Chau and Walker, 1988). 
Moreover, there are different types of productivity measurements such as multi-factor productivity and single-factor productivity. Terminologies differ in construction literature and terms are often used interchangeably, as 'productivity' with 'efficiency', 'multi-factor productivity' with 'total-factor productivity' and 'singlefactor productivity' with 'partial-factor productivity'. Multi-factor productivity is the ratio of output to the sum of multiple inputs associated with labour and capital, whereas single-factor productivity is the ratio of output to one input that is usually in the form of labour, capital or material (Tran and Tookey, 2011). Dolage and Chan (2013) pointed out the scarcity of academic publications focusing on multi-factor productivity in construction. The concept and indices for multi-factor productivity were developed in late 1940s by the National Bureau of Economic Research in the United States (De Valence and Abbott, 2015). The low volume of research on multi-factor productivity is generally associated with the complexity to accurately measure all the input resources consumed to achieve the output. However, the work of Goodrum et al. (2009) and Goodrum and Haas (2002) on multi-factor productivity is of high relevance where they measured technological productivity of construction in relation to change in material and equipment technology.

From the review of existing literature, Vogl and Abdel-Wahab (2015) established single-factor productivity measurement such as output per working hours adjusted for labour intensity as the most common productivity measurement method used by the researchers. The LP outputs can be based on gross output or the value added concept (Tookey, 2011). Although both multi-factor and single-factor productivity measurement methods have limitations, Janssen and McLoughlin (2008) distinguished that singlefactor productivity can be measured with reasonable reliability. 
Multi-factor productivity is beneficial in the setting where micro-macro links are established for analysis, such as one industry's contribution to economic productivity growth and living standards (Pilat and Schreyer, 2002). The major drawback of multifactor productivity is activated when the value added is double-deflated with a fixed weight Laspeyres index causing conceptual and empirical drawbacks of the concept (Pilat and Schreyer, 2002). However, multi-factor productivity provides the cross industrial ease of aggregation. Considering the limitations of methods and scope of queries, this research focuses on single-factor productivity based on the value added concept.

\subsection{Classification system}

The Eurostat database has largely been constructed on the basis of data from the National Statistical Institute (NSI) and processed according to harmonised procedures. The procedures are developed to ensure international comparability (O'Mahony and Timmer, 2009). Industrial classifications and definitions of the industrial sectors are harmonised for the statistical standards. NACE is practiced in the European community, North American Industrial Classification System (NAICS) is in the US, Canada and Mexico, International Standard Classification System (ISIC) is developed by the United Nations (UN) and Standard Industrial Classification is adapted in the UK. The revised edition of NACE (NACE Rev. 2) has designated section ' $F$ ' for construction, which contains 25 sub-classes, 23 classes, 9 groups and 3 divisions (see Table 1). The NACE Rev. 2 classification criterion is based on;

1. The production units classified under the same class must produce a significant share of total national production for group categorisation.

2. The production units in the sub-classes should achieve maximum homogeneity in relation to product's nature and field of utilisation. 
NACE Rev. 2 classifies business establishments based on the principal economic activity (Briscoe, 2006). The principal economic activity is the most important activity of the business establishment. Briscoe (2006) and Pearce (2003) argued that construction statistics fail to catch a substantial portion of construction activity from the organisations, because an organisation's principal business activity is registered under classifications other than construction in the national register.

Construction affects multiple industrial sectors, both directly and indirectly. Many organisations are involved in construction work, but their main business activity may not be construction. Briscoe (2006) indicated this problem in organisations such as health authorities, educational establishments, private-sector utilities and some transport undertakings which carry out a significant amount of construction work, but fail to distinguish it from the principal business activity. Moreover, modern organisations have attained service complexities in multiple sectors and seek reclassifications to their premier industrial sectors. Briscoe (2006) associated such switching behaviours of large organisations to impair reliability and cause discontinuity in the construction timeseries.

Table 1: Statistical Classification of the Construction Section (F) (NACE Rev. 2)

\begin{tabular}{|c|c|c|c|}
\hline Group & Class & Description of class & Subclass and description \\
\hline \multirow[t]{2}{*}{41.1} & & Development of building projects & \\
\hline & 41.10 & Development of building projects & $\begin{array}{l}\text { 41.101.House building cooperative } \\
\text { 41.109.Other develop/sale of real state }\end{array}$ \\
\hline \multirow[t]{2}{*}{41.2} & & Construction of buildings & \\
\hline & 41.20 & Construction of buildings & 41.200.Construction of buildings \\
\hline \multirow[t]{4}{*}{42.1} & & Construction of roads and railways & \\
\hline & 42.11 & $\begin{array}{llll}\begin{array}{l}\text { Construction } \\
\text { motorways }\end{array} & & & \text { roads and } \\
\end{array}$ & 42.110.Construction of roads and motorways \\
\hline & 42.12 & Construction of railways etc. & 42.120.Construction of railways etc. \\
\hline & 42.13 & Construction of bridges and tunnels & 42.130.Construction of bridges and tunnels \\
\hline \multirow[t]{3}{*}{42.2} & & Construction of utility projects & \\
\hline & 42.21 & $\begin{array}{l}\text { Construction of utility projects for } \\
\text { fluids }\end{array}$ & $\begin{array}{l}\text { 42.210.Construction of utility projects for } \\
\text { fluids }\end{array}$ \\
\hline & 42.22 & $\begin{array}{l}\text { Construction for utility projects for } \\
\text { electricity and telecommunications }\end{array}$ & $\begin{array}{l}\text { 42.220.Construction for utility projects for } \\
\text { electricity and telecommunications }\end{array}$ \\
\hline
\end{tabular}




\begin{tabular}{|c|c|c|c|}
\hline \multirow[t]{3}{*}{42.9} & & $\begin{array}{l}\text { Construction of other civil } \\
\text { engineering projects }\end{array}$ & \\
\hline & 42.91 & Construction of water projects & 42.910.Construction of water projects \\
\hline & 42.99 & $\begin{array}{l}\text { Construction of other civil } \\
\text { engineering projects } \\
\text { n.e.c. }\end{array}$ & $\begin{array}{l}\text { 42.990.Construction of other civil } \\
\text { engineering projects n.e.c. }\end{array}$ \\
\hline \multirow[t]{4}{*}{43.1} & & Demolition and site preparation & \\
\hline & 42.11 & Demolition & 42.110.Demolition \\
\hline & 42.12 & Site preparation & 42.120.Site preparation \\
\hline & 42.13 & Test drilling and boring & 42.130.Test drilling and boring \\
\hline \multirow[t]{4}{*}{43.2} & & Building Installation & \\
\hline & 43.21 & Electrical installation & 43.210.Electrical installation \\
\hline & 43.22 & $\begin{array}{l}\text { Plumbing heat and air conditioning } \\
\text { installation }\end{array}$ & $\begin{array}{l}\text { 43.221.Plumbing- and ventilation-install } \\
\text { 43.222.Refrigeration-/heat pump install. }\end{array}$ \\
\hline & 43.29 & Other construction installation & 43.290.Other construction installation \\
\hline \multirow[t]{6}{*}{43.3} & & Building completion and finishing & \\
\hline & 43.31 & Plastering & 43.310Plastering \\
\hline & 43.32 & Joinery installation & 43.320.Joinery installation \\
\hline & 43.33 & Floor and wall covering & 43.330.Floor and wall covering \\
\hline & 43.34 & Painting and glazing & $\begin{array}{l}\text { 43.341.Painting } \\
\text { 43.342.Glazing }\end{array}$ \\
\hline & 43.39 & $\begin{array}{l}\text { Other building completion and } \\
\text { finish }\end{array}$ & 43.390. Other building completion and finish \\
\hline \multirow[t]{3}{*}{43.9} & & Other special construction activities & \\
\hline & 43.91 & Roofing activities & $\begin{array}{l}\text { 43.911.Tinsmith work } \\
\text { 43.919. Other erec. of roof cov./frames }\end{array}$ \\
\hline & 43.99 & Other special construction activities & 43.990. Other special construction activities \\
\hline
\end{tabular}

A detailed examination of Table 1 reveals that it mainly incorporates the onsite construction activities, i.e., the physical assembly of construction and maintenance activities performed at the construction site. Pearce (2003) raised the issue of definition of construction sector and termed it as a narrow definition. Pearce (2003) associated the narrow definition of construction to the physical assembly and maintenance of dwellings, buildings and infrastructure, whereas in his broader definition of construction, he tries to capture the full scale of construction from off-site construction activities relating to products and services to the on-site construction activities associated with physical assembly. The report developed by Pearce (2003) stirred up debate in the academic community on whether the construction should be assessed based on the narrow definition provided in Table 1, or should it be reflected upon the 
true spectrum of construction. Several researchers debated upon the narrow definition of construction and tried to capture the full extent of construction activity including the peripheral industries that support the construction activity (Briscoe, 2006; Jewell and Flanagan, 2012; Squicciarini and Asikainen, 2011; Vogl and Abdel-Wahab, 2015).

Briscoe (2006) indicated that the most prominent gap is the NACE Rev. 2's failure to capture professional construction services and the construction products industry. Both of the gaps are related to off-site construction. Therefore, off-site construction is a major factor in the improvement of construction processes and site procedures (Taylor, 2010). This suggests that off-site construction factor is of significant value and cannot be ignored in construction LP calculations. The mining, manufacturing and service sector work in collaboration towards the buildability of onsite construction, where buildability is the most significant factor that influences the construction LP (Jarkas, 2015). The off-site construction industry has a twodimensional fragmented nature in terms of entities and processes (Alashwal and Fong, 2015). This refers to tangible construction elements that are prefabricated off-site and the knowledge-based solutions and expertise for the design and construction of the projects as construction processes. The weaknesses associated with these off-site construction products and services are discussed below.

\subsubsection{Construction Products}

Construction products are tangible entities associated with off-site construction industry. In this model, concrete modules can be produced in a factory and transported to the construction site for assembly (off-site) or can be cast on the construction site with the help of formwork (on-site) (Eastman and Sacks, 2008). The same applies to the possibility of producing various other construction elements such as façades, light steel frames and timber frames. A number of researchers (Ashworth and Hogg, 2014; 
Fawcett et al., 2005; Gibb and Isack, 2003) have encouraged off-site construction practices to improve the productivity of the on-site construction. According to Eastman and Sacks (2008), the categorisation of on-site and off-site construction activities can lead to a serious omission of many important productivity-enhancing innovations in construction, which is the dilemma the construction sector is facing today. Innovations in construction materials and off-site manufacturing technologies have improved the quality of construction products enhancing the life cycle value of the construction projects with a significant impact on productivity. However, off-site production activities such as the production of prefabricated elements, modules and building materials are classified under the manufacturing section in NACE Rev. 2, which means that a major portion of construction entities are represented in manufacturing industry statistics.

\subsubsection{Construction Services}

Construction services are the knowledge based processes and strategies in construction which influence the buildability of on-site construction. Construction services range over a variety of services from architects, technical services, whole sale and retail services of construction material, employment activities and renting and leasing of construction equipment. Technology improvements have dramatically changed the processes and quality of construction (Goodrum et al., 2009). Architects, design engineers, draughtsmen and construction managers have benefited a great deal from information technology (IT) in the last decade. Furthermore, different services from other industrial sectors are making their way into construction, for example employment activities where the entire labour contribution or a part of it is rented from the third party and the same is the case for renting and leasing of construction equipment. The new breed of construction organisations based on Public Private Partnership (PPP) 
projects are on the rise and the narrow definition of construction makes it virtually impossible for all these initiatives to register their construction activities in the construction statistics (Briscoe, 2006). Construction design services determine the onsite buildability and are responsible for design rationalisation, which is minimisation of the amount of material, sizes, components or sub-assemblies (Jarkas, 2015).

The service sector has an influential role in any national economy (Jewell and Flanagan, 2012) and accounts for 73\% of the United Kingdom's output (Office for National Statistics, 2010). Construction services have seen growth similar to the global service sector, which is responsible for one-fifth of worldwide trade in the balance of payments (United Nations, 2010). However, construction services are ignored in construction LP statistics.

\subsection{Input data}

Human interventions are widely measured in hours for construction LP research (Hanna et al., 2008; Thomas and Yiakoumis, 1987). Briscoe (2006) terms labour input in number of workers employed as a crude measure and recommends labour input in working hours as a more refined measure. NACE Rev. 2 only considers the working hours spent on the construction site by the workers as an input to construction LP. Calculating the working hours for labour is itself tricky due to various factors of data aggregation. Moreover, NACE Rev. 2 distinguishes between directly employed workers in the construction process and employees supporting the construction. The distinction excludes hired labour and the employees of subcontractors from the construction LP statistics, despite being a major part of modern day construction. NACE Rev. 2 do compromise seasonal adjustments to the data and take into account temporary employees, apprentices, holidays and sick leave data. According to Wang (1999), the exercise of capturing working hours data is often affected by factors like technology, 
government regulations, weather, unions, economic conditions, management and internal environment issues.

\subsection{Output data}

The output or product of the construction industry is heterogeneous due to the diverse nature of construction projects and objectives. It varies from roads and bridges to dams and housing (Vogl and Abdel-Wahab, 2015). The diverse outputs from the construction processes and sub-processes are both tangible and nontangible (Pekuri et al., 2011). This makes it difficult to measure construction output in physical units e.g., cubic meters. To counter such heterogeneity, outputs are measured in terms of holistic measures such as gross or value added (net output). Value added is the value created by the production, which is the value of outputs minus the value of both immediate consumption and consumption of fixed capital. Immediate consumption is documented by the purchaser price, which is the price the purchaser has paid for the product or service.

The value added at constant prices is the concept applied by economists for graphical presentation of a value added over time line. Statistical standards publish value added in terms of basic prices, which is the net amount entitled for the producer, i.e., the amount minus government taxes with the addition of any subsidies from the government for the particular product as a production or sale consequence. Comparison is a common purpose of productivity measurement (Chau and Walker, 1988). To represent productivity, data over a time series for historical comparisons requires a price reference for a certain reference year. Statisticians establish links from the value of the reference year by the annual percentage change in volume from year to year in each case. The change in volume remains the same from year to year but for a constant price, and the prices are subject to deflators for the comparisons. Links are established at both 
detailed and aggregate levels, where the aggregate values deviate from the detailed values over longer period of time, and the deviation is then adjusted by constant price estimates from the prices of the base year.

\section{Research methodology}

The theoretical footings of construction LP measurements in construction statistics are inspired by the work of Pearce (2003), Briscoe (2006), Squicciarini and Asikainen (2011), Jewell and Flanagan (2012) and Vogl and Abdel-Wahab (2015). The reference lists from the inspired authors were trailed to find the limitations of the statistical classifications and LP measurements. Scopus, the Norwegian library database (ORIA) and Google Scholar were explored with key search terms of 'labour productivity', 'workers' productivity', craftsmen's productivity' and 'construction statistics'. The search string revealed 320 publications on Scopus search engine. The research results from the search engines along with trailing back the reference lists of the above authors, resulted in a final selection of the literature for this study. Research theme of 'construction labour productivity' was developed with the help of final 68 relevant academic publications which were selected to gather the theory around the problem under investigation.

The theoretical analysis clarified the muddled picture of the classification of construction sector and construction LP measurements by statisticians. The theoretical generalisations served as a starting point towards constructive and participatory research philosophies. Creswell (2013) highlighted that social interaction and multiple participants meaning are the essence of the constructivist philosophy of knowledge generation. The research study engaged an expert team with three representatives from the Statistics Norway with macroeconomic and statistical expertise, one industry representative from the $\mathrm{EBA}^{*}$ to present their reservations about the current Statistics 
Norway's construction LP measurement practices, and an academic research group of six researchers from SINTEF* and NTNU* to find weaknesses in the Statistics Norway construction LP measurements. The expert group was engaged three times in a monthly workshop at the office of Federation of Norwegian Construction Industries to reflect on the Norwegian construction LP statistics. Inspired by Crotty (1998) and based on his social constructivism approach, the research consisted of open-ended research questions using qualitative research methods to engage participants in a broader discussion to develop deeper insights. The conclusions were reached with theoretical standpoints and reflections of the expert group on the academic literature, global statistical standards in practice, and modern construction practices.

The characteristics of sound empirical research, as described by Eisenhardt and Graebner (2007), begin with a strong literature grounding. As Azhar et al. (2009) indicated, there is need for a research approach in construction management that synthesises applied and basic research by creating scientific knowledge and solutions for practical problems. This study is a combination of qualitative and quantitative research methods. The academic evidence presented in this paper relates to the qualitative research, whereas the case study refers to the quantitative share of this study. Qualitative and quantitative research approaches represent the two ends of the research continuum (Yilmaz, 2013). To test the theory with the help of qualitative research, a case study was designed by the expert group to complete the research cycle.

\subsection{Design of case study}

It was established from the theoretical analysis that both on-site and off-site construction is vital parts of modern construction, which makes construction LP a sum of on-site and off-site LP. For this particular case study on Norwegian construction industry, off-site construction is approached with classification of construction products 
and services. The Norwegian construction industry was chosen in this study due to availability of the required data and other practical reasons including access. From here, the paper uses the word 'on-site construction' for the section F (construction) of NACE Rev. 2., whereas the term 'construction' will be used for the sum of on-site construction, construction products and services.

The case study is designed within the statistical limitations of Statistics Norway's statistical productivity data and the Norwegian National Accounts (NNA). Statistics Norway and NNA maintain the biggest and most credible statistical data set in Norway, and it is practically impossible to replicate such data for verification studies. Although the case study was designed with special reference to the Norwegian construction LP, the same approach is valid in the international arena of construction LP statistics as NACE Rev. 2 has developed standardised methods for international comparability of construction LP. However, the NACE Rev. 2 classification divided production activities into section, division, group and classes and subclasses. By scrutinising the production activities in the Statistics Norway business register, the production activities that supported on-site construction operations, but were not classified under the construction section were listed in a secondary set of activities. The secondary set of production activities was discussed in a workshop comprising the expert group members and negotiated with Statistics Norway for the possibility of data segregation.

Table 2: Weightage factors for Off-site Production Activities (OPA)

\begin{tabular}{lllll}
\hline $\begin{array}{l}\text { Statistical } \\
\text { Challenges }\end{array}$ & $\begin{array}{l}\text { Contributing } \\
\text { factor }\end{array}$ & $\begin{array}{l}\text { Classification } \\
\text { code }\end{array}$ & Off-site Production activities (OPA) \\
\hline 1 Construction & 1.00 & $\mathrm{C} 16$ & Manufacture of wood products except furniture \\
& products & 0.80 & $\mathrm{C} 23$ & Manufacture of non-metallic mineral products \\
& 0.28 & $\mathrm{C} 24$ & $\begin{array}{l}\text { Manufacture of basic metals except machine } \\
\text { and tools }\end{array}$ \\
& & &
\end{tabular}




\begin{tabular}{llll}
\hline 2 Construction & 0.50 & M71 & Architecture and engineering activities \\
services & 0.16 & G46 & Wholesale trade excluding motor vehicle \\
& 0.07 & G47 & $\begin{array}{l}\text { Retail trade except for motor vehicles and } \\
\text { motor cycles } \\
\end{array}$ \\
& 0.19 & $\mathrm{~N} 77$ & Rental and leasing \\
& 0.20 & $\mathrm{~N} 78$ & Employment activities
\end{tabular}

Some of the production activities from the secondary set such as activities related to mining of construction materials were marked out of scope because such activities have to go through multiple production processes to reach the construction site and each production process may result in different value gains. The secondary set was then reduced to a primary set of production activities, as presented in Table 2 . The expert group selected three production activities from the Norwegian business register to incorporate business activities associated with construction products. These include manufacturing of wood products except furniture, non-metallic mineral products and basic metals except machine and tools. Table 2 embodies the activities that resulted in construction services with a similar exercise.

For the contribution of each production activity, a contributing factor was established from the year 2013 with the help of NNA`s supply-use-tables adjusted for balance of payments. Each activity in the primary set of Off-site Production Activities (OPA) was assigned a factor with which it contributed towards the on-site construction section F of NACE Rev. 2 (see Table 2). As prices fluctuate over time and might lead to unrealistic comparisons, all the past and future pricing values were indexed to the pricing index of 2013. Pricing values for 2014 and 2015 were also forecasted based on year 2013. A fifteen year time span started from 2000 was selected due to special considerations of the revisions of statistical standards and the global financial crisis. 
Data categorisation of the construction process activity 'architectural and engineering' for the construction industry was not possible in the body of national data, which led the group to make a conservative assumption of dividing the data on architectural and technical services in half, where one half represents support for construction and other half supports other industries such as oil and gas. LP for all the activities in 2000 was set as a benchmark to examine logical productivity trends of construction-supporting activities over the agreed time span of 15 years. Value added and working hours data for all industries in Norway, on-site construction and each OPA for the period 20002015 was requested from Statistics Norway. Value added data for the construction support activities were treated with the respective contributing factor (see Table 2) for its contribution towards on-site construction. For logical comparison over the historical time series of 15 years, the value added data were indexed to Statistics Norway's published price index of 2013 and calculated in terms of relative percentage increase or decrease in LP from the preceding year. LP values in the year 2000 were set as the datum and point of origin with a designated value of $100 \%$.

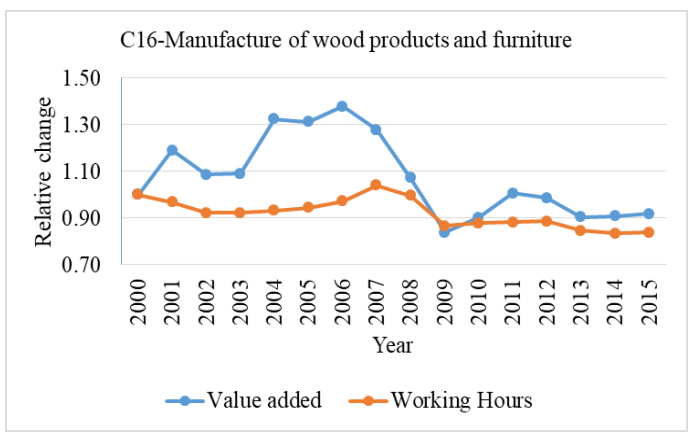

Figure 1: C16 Relative value-added and working hours

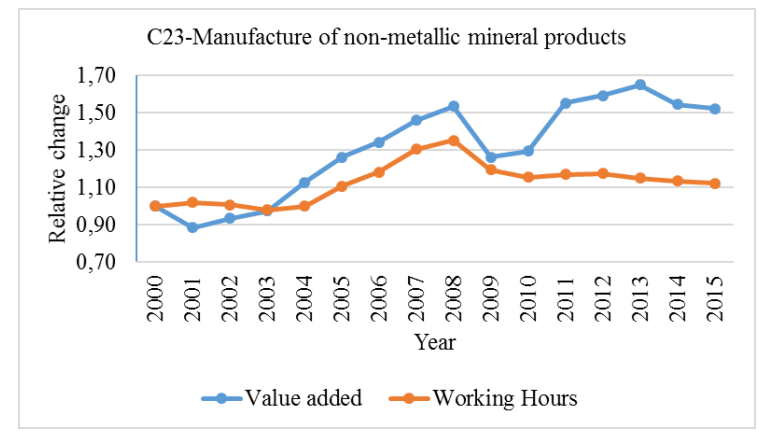

Figure 2: C23 Relative value-added and working hours 


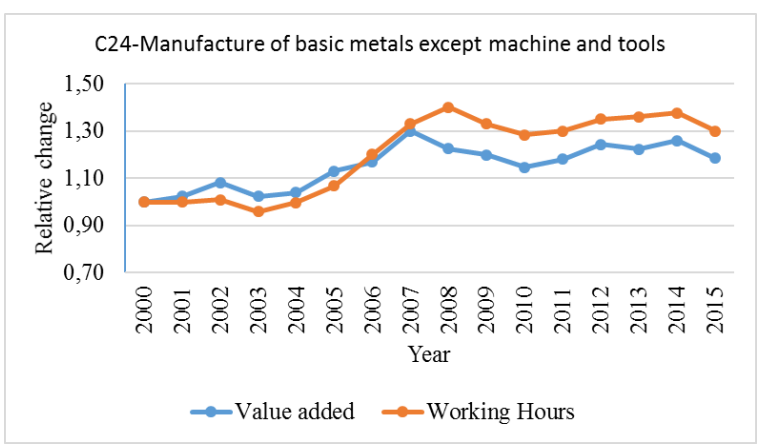

Figure 3: C24 Relative Value-added and working hours

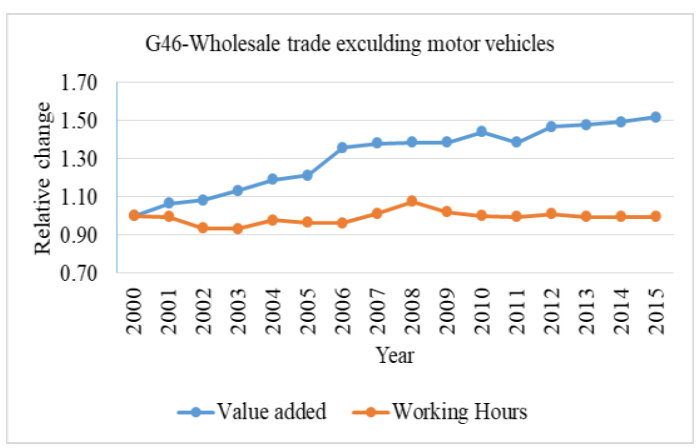

Figure 4: G46 Relative value-added and working hours

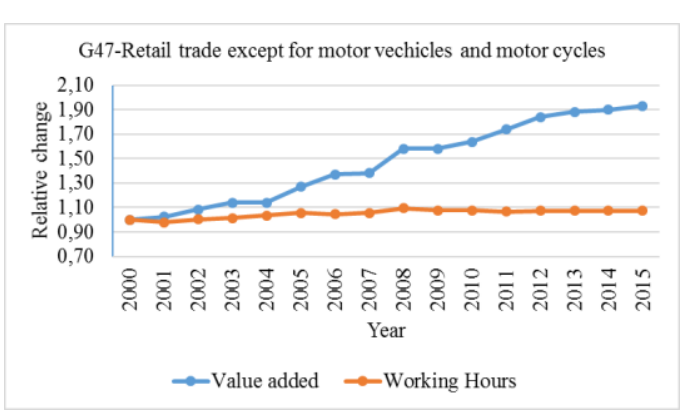

Figure 5: G47 Relative value-added and working hours

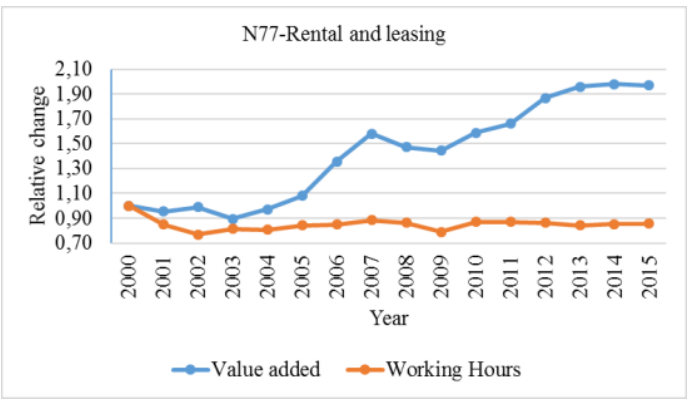

Figure 6: N77 Relative value-added and working hours

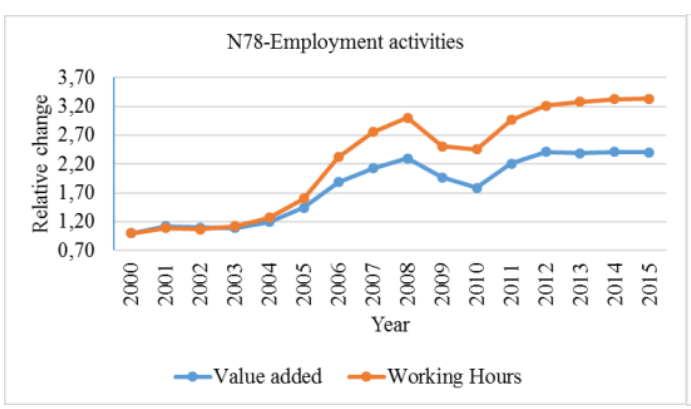

Figure 7: N78 Relative value-added and working hours

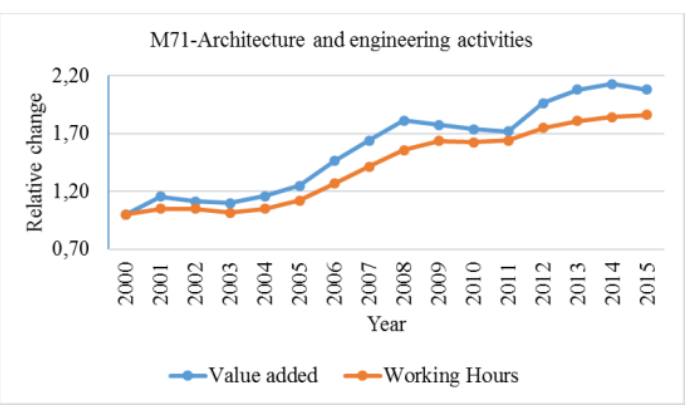

Figure 8: M71 Relative value-added and working hours

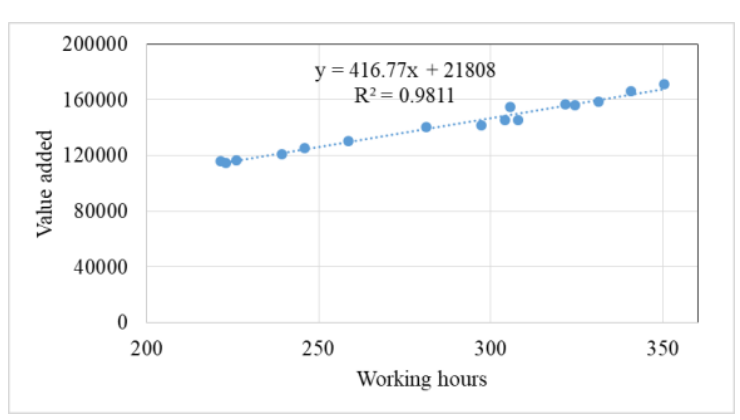

Figure 10: LP trend of construction and on-site construction
Figure 9: F Relative value-added and working hours

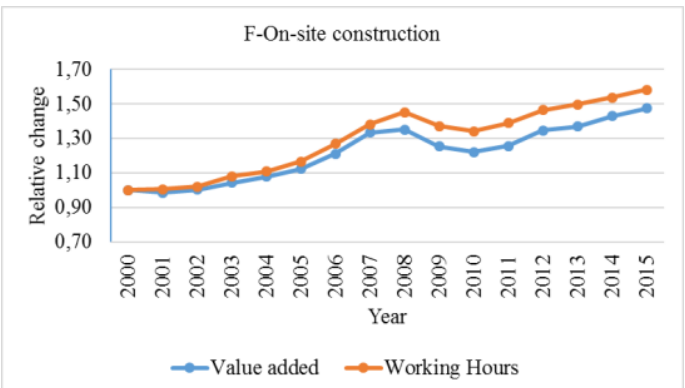




\section{Results and Discussion}

Construction industry, construction products and construction services vary from country to country. The laws and legal systems may also vary depending on the work force, climatic conditions and cost of material and production processes. According to Whitley and Kristensen (1996), construction industry of every nation is regulated and shaped by the national systems, which leave each national construction industry largely idiosyncratic. To explore the input (value-added) - output (working hours) trends in Norway, the selected OPAs were plotted relative to the value added by the activity and the working hours data with year 2000 as a datum and reference year of origin. The graphical representations of these relations are presented in Figure 1 to 9. As productivity increases by increasing output and decreasing the input in Figure 1 to 9, the diverging trend of value added-working hours reflect the increase in productivity of that activity, whereas converging trend reflects decrease in the LP of that activity.

The OPAs of 'Manufacture of basic metals except machine and tools', 'employment activities' and 'on-site construction' reflect a declining trend. The activities that have experienced real productivity gains are 'Wholesale trade excluding motor vehicle', 'Retail trade except motor vehicles and motor cycles' and 'Rental and leasing'. These activities are constantly producing more value with a relatively constant supply of work force. Whereas some activities such as 'Manufacture of wood products except furniture' and 'Manufacture of non-metallic mineral products' went through some historical turbulent trends with varying output (value added) in relation to the input (working hours). 


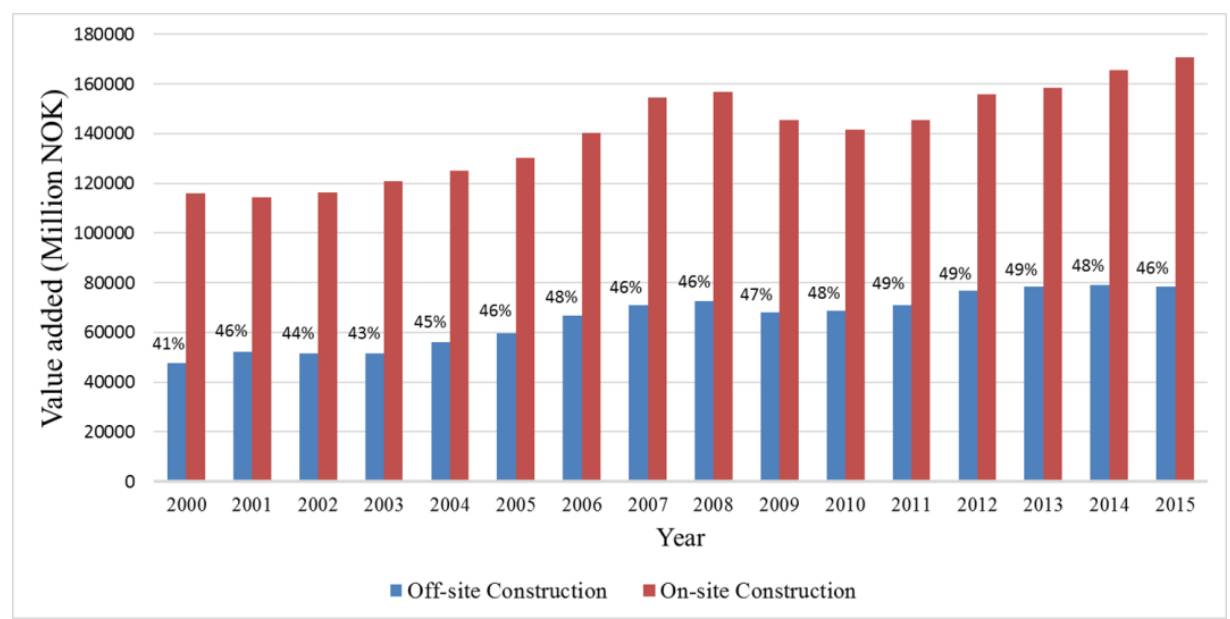

Figure 11: Percentage value added by off-site construction (OPAs) to on-site Construction (F)

The most noticeable are the trends in 'on-site construction', though it is a declining activity in terms of LP. The input and output data reflect a linear relation and stability. Such stable trend provides the researcher to roughly forecast the construction input or output. The value added and working hour's data for on-site construction is plotted in Figure 10. Apart from the turbulent times of global financial crisis, the LP trends of on-site construction have been linear with a stable growth. Figure 10 also presents the regression analysis for future prediction of on-site construction value in relation to the working hours.

The two major factors that affect the construction output significantly are the land and house prices (Tookey, 2011), given that construction is a labour intensive industry with major operations in the build area. The construction output might remain compromised in comparison to the other sectors such as manufacturing, mining or services. From the value added studies, Figure 11 reflects that around 41 to $50 \%$ of value of construction in relation to on-site construction $(F)$ is generated off-site. The sum of value is far greater to be ignored and not looked upon in the context of construction. Figure 11 also illustrates that value of off-site construction activities is coupled with on-site construction i.e. when the value addition of on-site construction 
declines the value addition of off-site construction activities declines with it. Through the years, the value gains have steadily shifted to the off-site construction and it peaked in 2011 to 2013 where $49 \%$ of total value of construction was generated off-site.

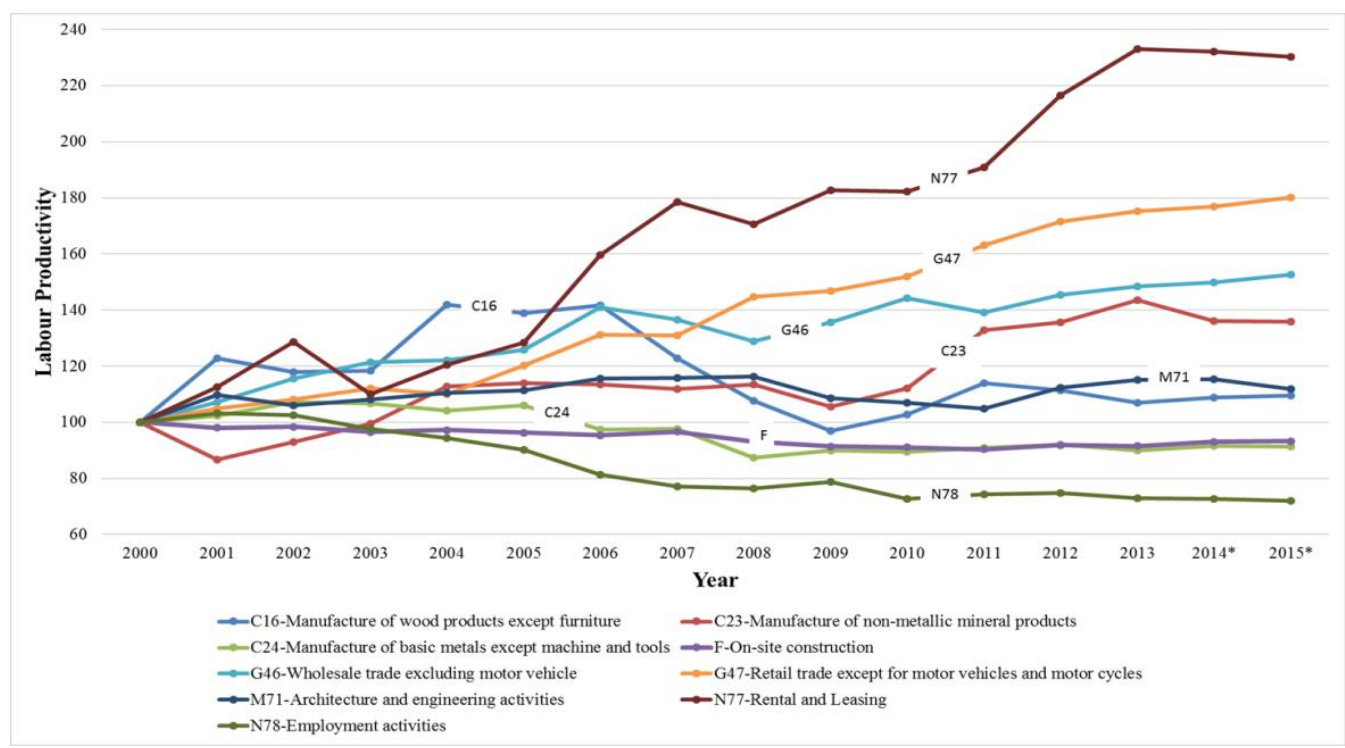

Figure 12: LP trends of on-site construction (F) and off-site construction activities (OPA)

In the valuation of the UK off-site construction sector, Taylor (2010) concluded that the true extent of off-site construction is underestimated and that the gross output is far greater than the former calculations. Figure 11 illustrates that the value generation in Norwegian off-site construction activities have steadily increased to approximately $50 \%$ of the value of on-site construction, which is a conservative estimate as our selected set of off-site construction activities might not represent the full scale of off-site construction activities. Briscoe (2006) questions the reliability of the construction statistics and highlights that output data such as gross and value added data are no longer useful for understanding the changing nature of construction activity.

The gross output data such as value added is also limited in providing the information about the change in quality of output. Although construction companies are paid for the quality they deliver to the private client, which in turn gets reflected in 
value calculations. The OPAs provide the liberty to implement strict quality controls and standardisation in terms of manufacturing strategies. This is turn have increased the quality of construction products manufactured off-site. The quality of these products has a considerable influence on the life cycle value of construction projects. However, the current statistical system fails to incorporate the change in quality of the construction output over time.

The adjusted and indexed LP of off-site construction activities (OPA) along with on-site construction are graphically plotted in Figure 12 for the span of 15 years (2000-2015). The OPAs reflect contribution towards the on-site construction from the Statistics Norway data. Figure 12 provides a unique LP comparison between the LP of on-site construction and OPAs. Considering the on-site LP over the years as a datum or line of reference reveals that LP in the supporting activities of construction employment and manufacturing of basic metals (excluding machines and tools) declined even more than on-site construction, reflecting a continuous declining trend. However, all other OPAs reflected a positive growth trend in LP, with rental and leasing activities surging to productivity gains of over two times that of construction LP. Compared with construction, the magnitude of these contrary differences in LP seems doubtful. One doubt is that Norwegian contractors in practice might have increased the renting and leasing of civil engineering equipment and machinery, which would shift the value gains of the construction sector to the service sector. This is similar to the manufacturing of construction products and assemblies. 


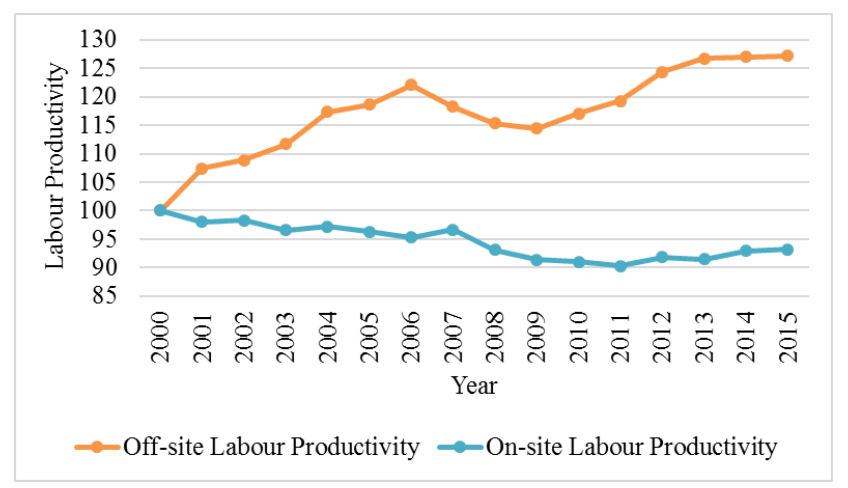

Figure 13: LP trend of On-site construction (F) Vs Off-site (OPA)

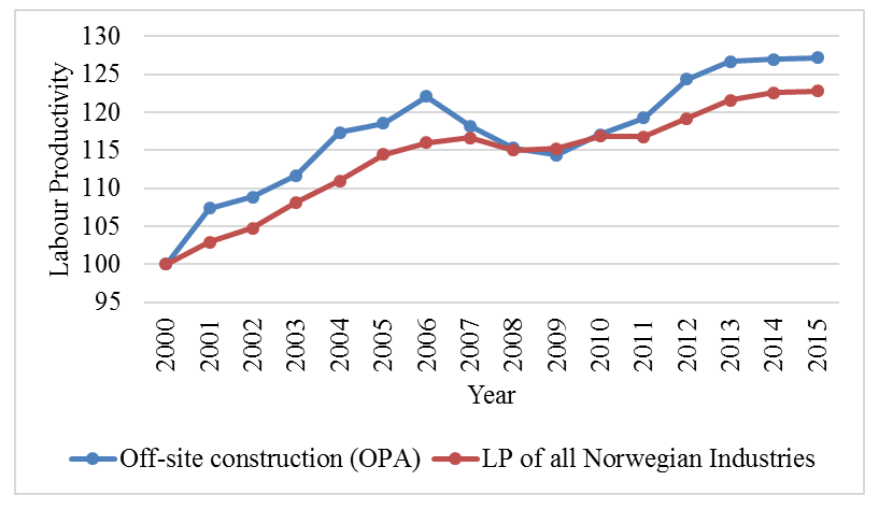

Figure 14: LP trends of off-site construction (OPA) Vs Norwegian industries

LP trend between off-site construction (OPA) and on-site construction is illustrated in Figure 13, which highlights that the off-site construction activities have seen larger gains on LP, whereas LP on-site has steadily declined over the years. To compare the LP of OPAs with the Norwegian LP of all industries, the aggregated sum of these contributing activities was compared to the LP of all Norwegian industries combined. The results are presented in Figure 14. The graphical representation in Figure 14 reveals that the LP of OPAs at all times from 2000 to 2015 remained higher than the LP of all Norwegian industries combined, except for the years of global financial crisis. Figure 14 also reflects the injustice done to the construction sector by the statistical classification of NACE Rev. 2, whereby the most labour-productive domains of construction are excluded from the construction LP measurements. Integrating the LP of OPAs into on-site construction $(\mathrm{F})$ resulted in construction LP presented in Figure 15. 
The modified construction LP reflects that construction LP is not declining. Construction is actually a productive industry when it comes to labour utilisation, though it might not be as productive as some other industries. In Figure 15, the dip in LP from 2008 to 2011 reflects the global financial crisis, which had an impact on the construction industry. However, after 2011, the construction industry's LP seems to be in recovery mode and improving. A better definition of the construction sector would not even just attract more attention from researcher and decision-makers, but will also claim a central policy stage for national productivity (Squicciarini and Asikainen, 2011).

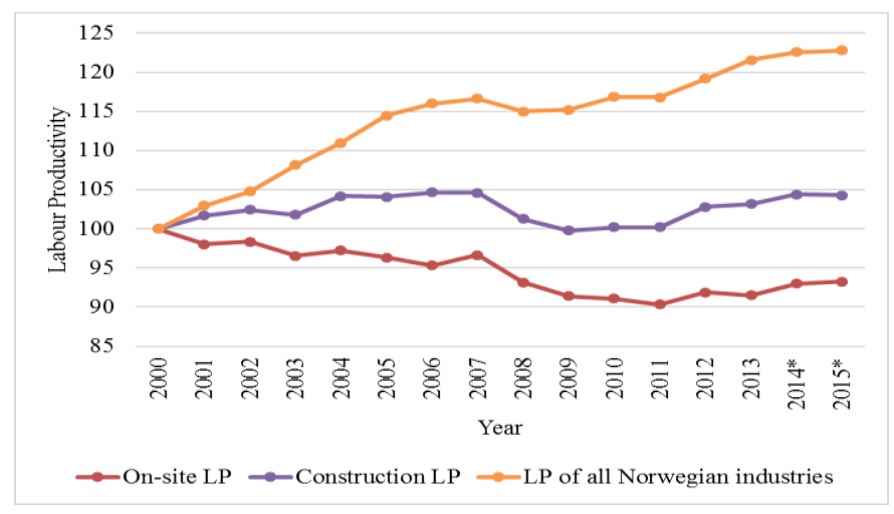

Figure 15: LP of on-site, Construction LP and LP of all Norwegian industries

The LP of on-site construction $(\mathrm{F})$ in comparison to construction LP (F+OPA) is presented in Figure 15 along with the LP of all Norwegian industries. For construction LP measurement, the LP sum of all OPAs is combined with the on-site construction to examine the LP trends with the improved spectrum of construction industry. The perception exists that construction is a technologically stagnant industry as compared to other industries. However, this belief in declining construction productivity is based on a number of studies that used industrial and macroeconomic data (Goodrum et al., 2009), whereas many researchers report anecdotal evidence that construction productivity has actually improved (Bernstein, 2003; Goodrum et al., 2002; 
Tuchman, 2004). The comparison graph in Figure 15 also falsifies the general assumption that construction is a declining industry in terms of LP. Construction LP might not be increasing with the LP rate of other sectors such as manufacturing. Construction LP might be stagnant but it is definitely not declining. Historically, changes in the statistics were initiated by the government statisticians (Briscoe, 2006), ignoring the construction industry which was most likely to use these statistics. Therefore, the failure to gauge the real productivity of the construction industry has exposed weaknesses in the statistical classification system. These weaknesses are not only taking their toll on the future growth potential of the largest industrial sector in the world, but also hampering investors' confidence, which is a necessary contributing factor in the development of the construction sector (Fox and Skitmore, 2007).

\section{Conclusions}

The construction industry's productivity measurements seem to be a victim of the statistical classification system. International statistical standards contributing towards global comparability define construction work only as the physical assembly of construction components at the construction site. This definition is narrow and fails to capture the real productivity and magnitude of the construction sector. Instead of revamping the construction classification system, it is possible to address and improve the weaknesses of construction LP measurements from within the statistical data. This study has indicated two weak areas of construction LP; namely construction products and services. The LP data of these weaknesses was integrated into construction LP to investigate the LP of the construction industry. The study reflects that OPA's are significantly more labour-productive than the on-site construction itself. Not only OPA's currently have a higher LP, but their rate of productivity growth is higher than the overall productivity of all Norwegian mainland industries combined. There is clear 
evidence that the OPAs have seen great gains in LP during 2000 to 2015, and Norwegian construction LP is not declining. However, due to the statistical classification system, these activities, though directly a part of the construction process, are instead contributing to the productivity statistics of the manufacturing and service industries. This raises questions about the LP results of other industry sectors.

Construction is still a labour-intensive industry that is complying with the everincreasing physical demands of the world. A reality check found that criticism on the Norwegian construction LP is exaggerated. The reliability of the national statistics is losing credibility in the ranks of the Norwegian construction industry, with contrasting LP calculations from the Norwegian labour unions and contractor associations. Norwegian construction has been modernised by integrating innovative technologies and practices. However, the statistical measurement system is persisting with a nonrepresentative and narrow definition of the industry, which excludes all the productivity gains of the construction industry from the published productivity statistics. A major part of on-site construction work is labour-intensive and cannot be modularised or standardised due to their complexity, yet only these on-site operations are reflected in the construction industry productivity statistics. It seems that most of the advances and modernisation in the construction industry for improving its productivity have only resulted in a negative representation in the Norwegian construction LP statistics. In order to maintain their credibility, the statistical standards need a better definition of construction sector that can capture the true scope of construction. This paper also reflects on the possibility of generating more reliable LP calculations, while remaining within the existing body of statistical data and aggregation methods. A similar exercise in the EU KLEMS and Eurostat member countries would be beneficial for streamlining 
the international comparisons of construction labour productivity and reflecting the real state of construction industry.

\section{References}

Abdel-Wahab, M., and Vogl, B. (2011). Trends of productivity growth in the construction industry across Europe, US and Japan. Construction Management and Economics, 29(6), 635-644.

Alashwal, A. M., and Fong, P. S. W. (2015). Empirical Study to Determine Fragmentation of Construction Projects. Journal of Construction Engineering and Management, 141(7). doi:10.1061/(asce)co.1943-7862.0000986

Ashworth, A., and Hogg, K. (2014). Added value in design and construction: Routledge.

Azhar, S., Ahmad, I., and Sein, M. K. (2009). Action research as a proactive research method for construction engineering and management. Journal of Construction Engineering and Management, 136(1), 87-98.

Briscoe, G. (2006). How useful and reliable are construction statistics? Building Research \& Information, 34(3), 220-229.

Chau, K., and Walker, A. (1988). The measurement of total factor productivity of the Hong Kong construction industry. Construction Management and Economics, 6(3), 209-224.

Creswell, J. W. (2013). Research design: Qualitative, quantitative, and mixed methods approaches: Sage Publications.

Crotty, M. (1998). The foundations of social research: Meaning and perspective in the research process: Sage Publications.

De Valence, G., and Abbott, M. (2015). A review of the theory and measurement techniques of productivity in the construction industry. Measuring Construction Prices, Output and Productivity. 205 - 221. Routledge.

Dolage, D., and Chan, P. (2013). Productivity in Construction-A Critical Review of Research. Engineer: Journal of the Institution of Engineers, Sri Lanka, 46(4).

Eastman, C. M., and Sacks, R. (2008). Relative productivity in the AEC industries in the United States for on-site and off-site activities. Journal of Construction Engineering and Management, 134(7), 517-526.

Edkins, A., and Winch, G. (1999). The performance of the UK construction industry: an international perspective. Bartlett Research Paper, University College London.

Eisenhardt, K. M., and Graebner, M. E. (2007). Theory building from cases: Opportunities and challenges. Academy of management journal, 50(1), 25-32.

Fawcett, R., Allison, K., and Corner, D. (2005). Using Modern Methods of Construction to build homes more quickly and efficiently. National Audit Office, London.

Fox, P., and Skitmore, M. (2007). Factors facilitating construction industry development. Building Research and Information, 35(2), 178-188.

Gibb, A., and Isack, F. (2003). Re-engineering through pre-assembly: client expectations and drivers. Building Research \& Information, 31(2), 146-160. 
Goodrum, P. M., and Haas, C. T. (2002). Partial factor productivity and equipment technology change at activity level in US construction industry. Journal of Construction Engineering and Management, 128(6), 463-472.

Goodrum, P. M., Haas, C. T., and Glover, R. W. (2002). The divergence in aggregate and activity estimates of US construction productivity. Construction Management \& Economics, 20(5), 415-423.

Goodrum, P. M., Zhai, D., and Yasin, M. F. (2009). Relationship between changes in material technology and construction productivity. Journal of Construction Engineering and Management, 135(4), 278-287.

Hanna, A. S., Chang, C.-K., Sullivan, K. T., and Lackney, J. A. (2008). Impact of shift work on labor productivity for labor intensive contractor. Journal of Construction Engineering and Management, 134(3), 197-204.

Janssen, J., and McLoughlin, S. (2008). New Zealand's productivity performance: New Zealand Treasury.

Jarkas, A. M. (2015). Effect of Buildability on Labor Productivity: A Practical Quantification Approach. Journal of Construction Engineering and Management, 142(2), 06015002.

Jewell, C., and Flanagan, R. (2012). Measuring construction professional services exports: a case for change. Building Research \& Information, 40(3), 337-347.

McNally, H. E., and Havers, J. A. (1967). Labor productivity in the construction industry. Journal of the Construction Division, 93(2), 1-12.

McTague, B., and Jergeas, G. (2002). Productivity Improvements on Alberta Major Construction Projects: Phase I-Back to Basics: Alberta economic development.

O'Mahony, M., and Timmer, M. P. (2009). Output, input and productivity measures at the industry level: the EU KLEMS database. The Economic Journal, 119(538), F374-F403.

OECD. (2001). Measuring Productivity: Measurement of Aggregate and Industry-level Productivity Growth: OECD Manual: Organisation for Economic Co-operation and Development.

OECD. (2015). OECD Compendium of Productivity Indicators 2015. Retrieved from Paris: http://dx.doi.org/10.1787/pdtvy-2015-en

Office for National Statistics. (2010). Annual abstract statistics No.146. Retrieved from Basingstoke:

Pearce, D. (2003). The social and economic value of construction. London, Davis Langdon Consultancy, nCRISP (New Construction Research and Innovation Strategy Panel).

Pekuri, A., Haapasalo, H., and Herrala, M. (2011). Productivity and Performance Management-Managerial Practices in the Construction Industry. International Journal of Performance Measurement, 1(1), 39-58.

Pilat, D., and Schreyer, P. (2002). Measuring productivity. OECD Economic studies, 2001(2), 127-170.

RCBCI. (2002). Productivity and performance in the building and construction industry. Royal Commission into the Building and Construction Industry (RCBCI), Melbourne, Victoria, Australia.

Rojas, E. M., and Aramvareekul, P. (2003). Is construction labor productivity really declining? Journal of Construction Engineering and Management, 129(1), 4146.

Ruddock, L. (2008). Economics for the modern built environment: Routledge. 
Singh, H., Motwani, J., and Kumar, A. (2000). A review and analysis of the state-ofthe-art research on productivity measurement. Industrial Management \& Data Systems, 100(5), 234-241.

Squicciarini, M., and Asikainen, A.-L. (2011). A value chain statistical definition of construction and the performance of the sector. Construction Management and Economics, 29(7), 671-693.

Tangen, S. (2005). Demystifying productivity and performance. International Journal of Productivity and performance management, 54(1), 34-46.

Taylor, M. D. (2010). A definition and valuation of the UK offsite construction sector. Construction Management and Economics, 28(8), 885-896.

Teicholz, P., Goodrum, P. M., and Haas, C. T. (2001). US construction labor productivity trends, 1970-1998. Journal of Construction Engineering and Management, 127(5), 427-429.

Thomas, H. R., and Yiakoumis, I. (1987). Factor model of construction productivity. Journal of Construction Engineering and Management, 113(4), 623-639.

Tinbergen, J. (1942). Zur theorie der langfristigen wirtschaftsentwicklung. Weltwirtschaftliches Archiv, 511-549.

Tookey, J. E. (2011). Labour productivity in the New Zealand construction industry: A thorough investigation. Construction Economics and Building, 11(1), 41-60.

Tran, V., and Tookey, J. (2011). Labour productivity in the New Zealand construction industry: A thorough investigation. Australasian Journal of Construction Economics and Building, 11(1), 41-60.

United Nations. (2010). Manual on international trade in services. Retrieved from New York, NY.

Vogl, B., and Abdel-Wahab, M. (2015). Measuring the Construction Industry's Productivity Performance: Critique of International Productivity Comparisons at Industry Level. Journal of Construction Engineering and Management, 141(4). doi:10.1061/(asce)co.1943-7862.0000944

Wang, S. Q. (1999). Improving Construction Productivity by Management. Paper presented at the Proceedings of the 2nd International Conference on Construction Industry Development and 1st Conference of CIB TG29 on Construction in Developing Countries: Construction Industry Development in the New Millennium, 27-29 October 1999, The Pan Pacific Hotel, Singapore.

Whitley, R., and Kristensen, P. H. (1996). The changing European firm: limits to convergence: Cengage Learning EMEA.

Yilmaz, K. (2013). Comparison of Quantitative and Qualitative Research Traditions: epistemological, theoretical, and methodological differences. European Journal of Education, 48(2), 311-325. 